\title{
PENGARUH PENGGUNAAN SISTEM PEMILIHAN UMUM DEWAN PERWAKILAN RAKYAT PROPORSIONAL DAFTAR TERBUKA
}

(The Effect of Using Open List Proportional of Legislative Election System)

\author{
Muhamad Doni Ramdani dan Fahmi Arisandi \\ Fakultas Hukum Universitas 17 Agustus 1945 Jakarta \\ Jl. Sunter Permai Raya Sunter Agung Podomoro Jakarta Utara \\ Email: m_dr89@yahoo.com / fahmi_adventure05@yahoo.com
}

Naskah diterima: 20 Maret 2014; revisi: 11 April 2014; disetujui: 29 April 2014

\begin{abstract}
Abstrak
Persoalan sistem pemilu anggota Dewan Perwakilan Rakyat dengan sistem proporsional daftar terbuka memang sudah berakhir, setelah diputuskan oleh Mahkamah Konstitusi pada tahun 2008. Namun dengan putusan Mahkamah Konstitusi tersebut, persoalan baru muncul, semakin tingginya biaya politik serta munculnya persaingan para calon anggota legislatif saling berlomba untuk menarik simpati dari masyarakat tidak hanya persaingan antar partai politik tetapi juga dalam satu partai yang sama. Pengaruh yang timbul dari penerapan sistem pemilu proporsional daftar terbuka menjadi menarik untuk dikaji kembali. Penulisan ini menggunakan metode penelitian hukum normatif, yaitu penelitian yang didasarkan pada data sekunder. Hasil penelitian menunjukan terdapat beberapa pengaruh yang timbul dari penerapan sisten pemilu proporsional daftar terbuka, selain biaya politik yang menjadi mahal berdampak pada banyaknya para anggota Dewan Perwakilan Rakyat yang terbukti korupsi mengingat modal untuk menjadi anggota legislatif yang sangat tinggi. Persoalan tidak mencukupi Bilangan Pembagi Pemilih para calon memungkinkan parpol yang pada akhirnya yang memiliki kewenangan untuk menentukan calon yang akan duduk di parlemen.

Kata Kunci: Pemilihan Umum, Dewan Perwakilan Rakyat, Proporsional Daftar Terbuka
\end{abstract}

\section{Abstract}

The issue of election system for member of House of Representatives with an open list proportional system is already over, after it was decided by the Constitutional Court in 2008. Yet with that verdict of the Constitutional Court, another problems emerging, it increases high cost of political competition and the emergence of the legislative candidates competing to attract the sympathy of the community is not only competition between political parties but also within the same party. Influence arising from the application of open list proportional election system becomes interesting to study again. This writing method is normative legal research, which is research based on secondary data. The results showed there were some influences arising from the application of the election systems of proportional open list, in addition political costs being expensive it have an impact on the number of members of the House of Representatives has proved to be corrupted regarding the capital to be members of the House of Representatives is very high. The issue of insufficient numbers of dividers voters for candidates of House of Representatives allows political parties who ultimately has the authority to determine which candidates will sit in parliament.

Keywords: The General election, the House of Representatives, the Open List Proportional 


\section{A. Pendahuluan}

Perdebatan persoalan sistem pemilihan umum (pemilu) anggota Dewan Perwakilan Rakyat (DPR) dengan sistem proporsional daftar terbuka telah berakhir, setelah diputuskan oleh Mahkamah Konstitusi (MK) pada tahun 2008. Namun dengan putusan MK tersebut, timbul persoalan baru, yakni biaya politik yang dirasa semakin mahal mengingat persaingan para calon anggota legislatif (caleg) saling berlomba untuk menarik simpati dari masyarakat tidak hanya persaingan antar partai politik tetapi juga dalam satu partai yang sama. Meskipun telah ada upaya untuk membatasi biaya kampanye, namun para caleg telah melakukan kampanye jauh sebelum Komisi Pemilihan Umum (KPU) menetapkan waktu untuk berkampanye. Akibatnya para caleg yang telah terpilih cenderung korup, hal ini dapat dilihat dari banyaknya anggota legislatif yang tertangkap oleh Komisi Pemberantasan Korupsi (KPK) baik di tingkat pusat maupun di tingkat daerah.

Sistem pemilu di Indonesia telah mengalami perubahan, dari sistem proporsional daftar tertutup (closed-list $P R$ ) menjadi sistem proporsional daftar terbuka (open-list $P R$ ). Tetapi, karena perubahan itu tidak sepenuhnya terbuka, sistem baru itu lebih tepat disebut sebagai sistem proporsional semi daftar terbuka (semi-open-list PR). Hal ini terjadi karena penentuan tentang siapa yang akan mewakili partai di dalam perolehan kursi di DPR/D tidak didasarkan pada perolehan suara terbanyak melainkan tetap berdasarkan nomor urut. Kalaupun ada calon di luar nomor urut, calon itu harus memiliki suara yang mencukupi Bilangan Pembagi Pemilih (BPP). Padahal syarat demikian sangat berat dipenuhi. ${ }^{1}$ Sehingga pada kenyataannya banyak caleg yang lolos sebetulnya tidak memenuhi syarat BPP tersebut.

Akibat putusan MK Nomor 22 dan 24/ PUU-VI/2008 yang mengabulkan permohonan pengujian undang-undang (judicial review) Pasal 214 Undang-undang Nomor 10 Tahun 2008 tentang Pemilihan Umum Anggota DPR, DPD dan DPRD, mengubah sistem Pemilu legislatif dari sistem proporsional tertutup menjadi proporsional sistem terbuka (Pasal 5 Ayat 1 Undang-Undang Nomor 10 Tahun 2008) dengan suara terbanyak. Permasalahan yang muncul adalah putusan MK tersebut bukan merupakan terobosan politik yang pantas diapresiasi sebagai wujud keterwakilan rakyat, karena putusan itu tidak serta merta diikuti dengan pelaksanaan teknis bahkan menimbulkan kekosongan hukum pada proses penetapan caleg berdasarkan suara terbanyak. Karena MK juga tidak menjelaskan secara rinci apakah suara terbanyak dalam arti mayoritas atau pluralitas.

Mengingat sistem pemilu yang sudah dimodifikasi dan megalami sedikit perbaikan itu masih tidak lepas dari kekurangan, terdapat usulan untuk melakukan modifikasi sistem proporsional lanjutan. Jika pada pemilu 2004 sudah dipakai sistem daftar setengah terbuka (semi-open-list $P R$ ), untuk pemilu-pemilu selanjutnya terdapat usulan digunakannya sistem daftar terbuka (open-list PR). Di dalam sistem demikian, nomor urut di dalam daftar calon tidak lagi dijadikan ukuran untuk menentukan calon mana yang mewakili partai di

Kacung Marijan, Sistem Politik Indonesia; Konsolidasi Demokrasi Pasca-Orde Baru (Jakarta: Kencana, 2012), hlm. 95. 
dalam perolehan kursi sekiranya tidak ada calon yang memenuhi BPP. Suara terbanyak dijadikan ukuran dalam menentukan calon yang terpilih. ${ }^{2}$

Susilo Bambang Yudhoyono mengusulkan sistem demikian, karena sistem ini baik untuk partai sehingga semua calon akan bekerja keras untuk partainya. Rakyat juga mendapatkan pilihan yang lebih jelas. Sebab, siapa yang paling banyak memperoleh suara, akan masuk ke parlemen tanpa memakai nomor urut yang kriterianya tidak jelas dan menjadi sumber politik uang. ${ }^{3}$

Pro-kontra tentang penerapan sistem pemilihan anggota DPR dengan proporsional terbuka memang sempat menguat dan menjadi pembahasan revisi Undang-undang Nomor 10 Tahun 2008 tentang Pemilu Legislatif menjadi Undang-undang Nomor 8 Tahun 2012 yang sempat diwarnai usulan agar sistem pemilu kembali ke sistem proporsional tertutup. Namun, suara yang mendukung usulan itu lemah. Sistem proporsional terbuka dengan perolehan terbanyak tetap dianggap terbaik. Sistem ini telah diputuskan oleh MK beberapa bulan sebelum pemilu legislatif 2009 dimulai. Kecil kemungkinan MK mau mengubah keputusan tersebut. ${ }^{4}$

Sistem pemilu proporsional terbuka terus disorot karena dinilai sebagai pemicu tingginya biaya politik, khususnya bagi calon legislator.
Pramono Anung Wibowo, memprediksi biaya kampanye masing-masing calon anggota legislatif DPR RI untuk Pemilu 2014 akan naik rata-rata satu setengah kali lebih tinggi dibandingkan dengan biaya yang dikeluarkan pada Pemilu 2009. Dengan asumsi rata-rata biaya kampanye pada 2009 mencapai 3,3 miliar rupiah, maka pada tahun depan diperkirakan biaya itu akan mencapai 4,5 miliar rupiah. ${ }^{5}$

\section{B. Permasalahan}

Berdasarkan latar permasalahan diatas, penulis merumuskan permasalahan; Bagaimana pengaruh penggunaan sistem pemilihan umum Dewan Perwakilan Rakyat (DPR) dengan sistem proportional daftar terbuka?

\section{Metode Penelitian}

Penelitian ini merupakan jenis penelitian hukum normatif, ${ }^{6}$ yaitu merupakan penelitian hukum yang dilakukan dengan cara meneliti bahan kepustakaan atau data sekunder. Penelitian ini terutama difokuskan pada penelitian atas bahan-bahan berupa peraturan perundang-undangan maupun dokumen resmi seperti putusan pengadilan ${ }^{7}$ yang berkaitan dengan sistem pemilu legislatif di Indonesia. Penelitian ini disajikan dalam bentuk deskriptif analisis. Pengumpulan bahan hukum dilakukan

Ibid., hlm. 96.

Ibid. hlm. 97.

Lihat Dwi Aroem Hadiati "Sistem Proporsional Terbuka Masih Pilihan Terbaik" dalam: http://politik.kompasiana. com/2014/01/07/sistem-proporsional-terbuka-masih-pilihan-terbaik-626328.html, (diakses 25 Februari 2014).

5 Lihat: Nurul "Tidak Ada System Pemilu Yang Dianggap Terbaik" dalam http://id.voi.co.id/voi-komentar/4955tidak-ada-system-pemilu-yang-dianggap-terbaik, (diakses 26 Februari 2014).

Soerjono Soekanto dan Sri Mamudji, Penelitian Hukum NormatifSuatu Tinjauan Singkat (Jakarta: PT RajaGrafindo Persada, 2009), hlm. 12-15.

7 Kenneth D. Bailey, Methods of Social Research, Second Edition (New York: The Free Press-Devision of MacMillan Publishing Co. Inc, 1982), hlm. 62-63. 
dengan studi kepustakaan terhadap bahan hukum primer dan bahan hukum sekunder seperti peraturan perundang-undangan dan buku-buku literatur terkait.

\section{Pembahasan}

\section{Sistem Pemilu di Indonesia}

Secara sederhana, sistem pemilu berarti instrumen untuk menerjemahkan perolehan suara di dalam pemilu ke dalam kursi-kursi yang dimenangkan oleh partai atau calon. Adapun variabel-variabel dasar yang sering dipakai mencakup formula pemilihan (electoral formula), struktur penyuaraan (ballot structure), dan besaran distrik (district magnitude). ${ }^{8}$

Mengingat variabel-variabel di dalam sistem pemilu yang ada itu cukup beragam, implikasi dari penggunaan sistem pemilu juga berbedabeda. Secara teoritis, perbedaan itu khususnya berkaitan dengan derajat keterwakilan politik dari para wakil yang terpilih melalui pemilu, dan implikasinya terhadap stabilitas pemerintahan yang terbangun melalui pemilu. Karena itu, sejak lama, baik dikalangan akademis maupun praktisi, perbedaan tentang sistem pemilu mana yang terbaik dan sesuai untuk negara tertentu selalu dilakukan.

Sejak pemilu tahun 1955 Indonesia menganut sistem pemilu proporsional. Di dalam sistem ini, alokasi jumlah kursi di lembaga perwakilan didasarkan pada perolehan suara masing- masing peserta pemilu secara proporsional. Alokasi dan distribusi kursi didasarkan pada jumlah penduduk. Tetapi, untuk luar Jawa tidak sepenuhnya berdasarkan jumlah penduduk. Hal ini dilakukan sebagai upaya untuk membuat keseimbangan antara wakil dari Jawa yang sempit namun besar penduduknya berbeda dengan luar Jawa yang luas wilayahnya tetapi lebih sedikit jumlah penduduknya. Sedangkan metode pembagian kursinya lebih banyak menggunakan metode the largest remainder dan Kuota Hare. 9

Sistem proporsional terbuka terbatas yang dianut Undang-Undang Nomor 10 Tahun 2008, yakni sistem yang ditandai dengan penentuan calon terpilih berdasarkan nomor urut tersebut tidak dapat lagi dilaksanakan, karena MK telah mencabut sistem proporsional daftar calon terbuka terbatas dan menggantikannya dengan sistem proporsional terbuka murni. ${ }^{10}$

Lahirnya sistem proporsional terbuka murni berawal dari dikabulkannya gugatan judicial review $^{11}$ oleh MK terhadap ketentuan Pasal 214 Undang-Undang Nomor 10 Tahun 2008. Pasal tersebut dinilai inkonstitusional ${ }^{12}$ karena bertentangan dengan prinsip kedaulatan rakyat yang dianut dalam Undang-Undang Dasar 1945. Pasal 214 Undang-Undang Nomor 10 Tahun 2008 dinilai inkonstitusional karena bertentangan dengan makna substantif kedaulatan rakyat dan bertentangan dengan prinsip keadilan 
sebagaimana diatur dalam Pasal 28D ayat (1) UUD $1945 .^{13}$

Pasal 1 ayat (2) UUD 1945 yang menyatakan bahwa kedaulatan berada di tangan rakyat dan dilaksanakan menurut UUD 1945 ditafsirkan MK bahwa kedaulatan tertinggi berada di tangan rakyat, sehingga dalam kegiatan pemilu, rakyat langsung memilih siapa yang dikehendakinya. ${ }^{14}$ Terkait hal ini, MK sebagai lembaga yang kompeten menafsirkan UUD 1945 berpendapat bahwa tujuan utama pelaksanaan kedaulatan rakyat sebagai prinsip dasar konstitusi adalah dalam rangka menempatkan sedemikian rupa penghargaan dan penilaian hak suara pemilih yang membentuk wujud kedaulatan, tidak merupakan masalah yang tunduk pada perubahan yang timbul dari kontroversi politik di DPR, seperti menempatkan kekuasaan partai politik untuk mengubah pilihan rakyat menjadi pilihan penguasa partai politik melalui nomor urut. $^{15}$

Pendapat MK tersebut menepis pendapat yang menyatakan bahwa pembuat undangundang berdasarkan kebijaksanaanya dapat menentukan sistem pemilu apa saja yang diingini. Benar pembuat undang-undang diberikan kewenangan untuk menentukan sistem pemilu yang akan ditetapkan, namun pembuat undang-undang tidak dapat keluar dari garis ataupun prinsip-prinsip kedaulatan rakyat yang dianut UUD 1945 sebagai konstitusi negara. ${ }^{16}$
Mahkamah Konstitusi berpendapat bahwa untuk terwujudnya kondisi di mana rakyat langsung memilih siapa yang dikehendakinya, maka akan lebih sederhana dan mudah ditentukan siapa yang berhak terpilih dengan cara atau berdasarkan pada perolehan suara atau dukungan rakyat paling banyak. ${ }^{17}$ Dengan demikian, Pasal 214 Undang-Undang Nomor 10 Tahun 2008 telah melanggar dua prinsip secara bersamaan, yaitu prinsip kedaulatan rakyat dan keadilan yang dianut UUD 1945. MK juga menilai, keberadaan Pasal 214 Undang-Undang Nomor 10 Tahun 2008 akan mengganggu kedaulatan rakyat dan keadilan. Jika ada dua caleg yang mendapat suara yang jauh berbeda ekstrim, terpaksa caleg yang mendapatkan suara terbanyak dikalahkan caleg yang mendapat suara kecil, namun dengan nomor urut lebih kecil. ${ }^{18}$

Tjahjo Kumolo mengemukakan, bahwa penghapusan nomor urut itu justru akan membuka peluang adanya politik uang. ${ }^{19}$ Disamping itu, sistem demikian dianggap akan mendeligitimasi keberadaan partai, Jusuf Kalla juga menuturkan bahwa perlu tetap mempertahankan sistem semi terbuka, lebih lanjut menuturkan bahwa dengan sistem terbuka tanpa nomor urut, bisa dilakukan secara teoritis, tetapi sulit untuk dipraktikan.

Negara yang berlandaskan pada kedaulatan rakyat dalam pelaksanaannya merupakan satu

\footnotetext{
13 Putusan Mahkamah Konstitusi Nomor 22-24/PUU-VI/2008 dalam Perkara Pengujian Undang-Undang Terhadap Undang-Undang Dasar, tanggal 19 Desember 2008.

14 Ibid., hlm. 102.

15 Ibid., hlm. 103.

16 Khairul Fahmi., Op. Cit., hlm. 267.

17 Putusan Mahkamah Konstitusi..., Op.Cit., hlm. 104.

18 Khairul Fahmi, Op. Cit., hlm. 267-268.

19 Lihat dalam Kacung Marijan, Op.Cit., hlm. 97. Lihat pula dalam Tempo Interaktif, 14-15 Desember 2006. http:// tempo.co.id/hg/nasional/2006/12/14/brk,20061214-89505,id.html.
} 
kesatuan dengan pelaksanaan konsep negara hukum atau nomokrasi. Hal ini dapat terlihat dalam ketentuan UUD 1945 yang menyatakan bahwa negara Indonesia adalah negara hukum dimana kedaulatan berada di tangan rakyat (constitutional democracy based on rule of law). Ketentuan ini mendasarkan atas pelaksanaan kedaulatan haruslah tetap berpegang pada asas-asas hukum agar pelaksanaan kedaulatan ini tidak menimbulkan kekacauan.

Salah satu bentukasaskedaulatan rakyatyang bersandarkan atas hukum adalah pelaksanaan pemilu untuk memilih para wakil rakyat melalui konsep demokrasi ${ }^{20}$ perwakilan. Dalam hasil diskusinya, International Commission of Jurist menetukan syarat-syarat representative government under the rule of law dimana salah satunya adalah adanya pemilu yang bebas. ${ }^{21}$ Pemaknaan bebas disini menurut Ruppert Shick adalah bahwa para pemilih tidak dipaksa dan berada di bawah tekanan dalam pengguaan hak pilihnya. ${ }^{22}$ Pemilih tidak "digiring" ke tempat pencoblosan agar rela merestui tatanan politik yang ada dan tidak terdapat kebebasan memilih atau peluang memilih kontestan sebagaimana di negara-negara totaliter. ${ }^{23} \mathrm{Hal}$ yang sama mengenai ketidakbebasan dalam memilih pun terjadi di negara-negara otoriter dimana rakyat diperkenankan memilih sejumlah konstestan yang telah dikebiri dan dilitsus. ${ }^{24}$ Dengan demikian, pelaksanaan pemilu di kedua jenis negara tersebut hanyalah bersifat formalitas belaka.

Berbicara mengenai kedaulatan, maka hal tersebut identik dengan pengertian kekuasaan tertinggi dalam penyelenggaraan kegiatan bernegara. Dalam membahas mengenai kedaulatan, maka akan timbul persoalan mengenai apa dan siapa yang memegang kekuasaan tertinggi dan membuat keputusan akhir dalam kegiatan kenegaraan. ${ }^{25}$ Sehingga dalam konsep negara modern, pemegang kedaulatan diidentikkan dengan istilah demokrasi yang menurut asal katanya bermakna rakyat yang berdaulat atau government or rule by the people ${ }^{26}$ sehingga pemegang kedaulatan

20 Carol C. Gould mengklasifikasikan teori demokrasi kepada tiga model, yaitu: (1) model individualisme liberal, (2) model pluralisme, dan (3) model sosialisme holistik. Teori individualisme liberal memahami individu atau orang sebagai dasar entitas yang menyusun masyarakat. Teori ini memberikan tekanan pada kebebasan individu yang sederajat untuk bebas memilih dengan menolak adanya intervensi dari luar dalam bentuk apapun. Model pluralisme memusatkan perhatian pada kepentingan kelompok sebagai agregasi dari kepentingan individual, dan pemunculanya akan mengakibatkan konflik dalam proses politik. Sehingga demokrasi politik ditafsirkan sebagai sistem pemerintahan yang menengahi konflik (kompetisi) itu untuk memperoleh keseimbangan sosial. Model sosialisme holistik merupakan salah satu pendekatan yang menekankan demokrasi ekonomi dan muncul untuk menanggapi ditolaknya kenyataan hubungan sosial dan ekonomi yang dilontarkan oleh individualisme liberal. Dalam Hendra Nurtjahjo, Filsafat Demokrasi (Jakarta; Bumi Aksara, 2006), hlm. 31.

21 Sri Soemantri, Tentang Lembaga-Lembaga Negara Menurut UUD 1945, $4^{\text {th }}$ ed. (Bandung: Citra Aditya Bakti, 1989), hlm. 12-13.

22 Ruppert Shick and Wolfgang Zek, The German Budestag: Functions And Procedurs, $1^{\text {st }}$ ed., (Rheinbretbach: Neve Darmstadter Verlagsanstalt, 1999), hlm. 11.

23 Pipit R. Kartawidjaja dan Mulyana W.Kusumah, Sistem Pemilu Dan Pemilihan Presiden: Suatu Studi Banding (Jakarta: KIPP Eropa, Friedrich Naumann Stiftung dan Indonesian Society For Democracy And People Employment, tt, 2002), hlm. 1.

24. Ibid.

25 Jimly Asshiddiqie, Pokok-Pokok Hukum Tata Negara Indonesia Pasca Reformasi, $2^{\text {nd }}$ ed. (Jakarta: PT Bhuana Ilmu Populer, 2008), hlm. 144.

26 Miriam Budiarjo, Dasar-Dasar Ilmu Politik, $2^{\text {nd }}$ ed. (Jakarta: PT Gramedia, 1978), hlm. 50. 
tertinggi dalam suatu negara modern adalah rakyat itu sendiri.

Apabila kita kembali kepada konsep teoritis, hak memilih merupakan salah satu dari hak asasi manusia yang diakui secara interasional. Hak asasi memilih akan terpenuhi bila hak asasi manusia secara keseluruhan dihormati dan diperlakukan sebagai hak yang melekat dalam diri setiap manusia semata karena seseorang adalah manusia dan karena itu hak memilih bukan pemberian atau pinjaman negara. ${ }^{27}$ Sistem pemilu yang tidak mendorong aspirasi masyarakat dalam menggunakan haknya, berarti sistem pemilu tersebut mengebiri bahkan menghilangkan penggunaan hak asasi manusia itu sendiri. Padahal pemilihan sistem pemilu ini sangat mempengaruhi komposisi badan pemerintahan terpilih (salah satunya adalah parlemen), struktur sistem partai politik, proses pembentukan opini publik dan kehendak para pemilih, kemampuan dan kapasitas penduduk untuk berpartisipasi dalam proses politik serta akan mempengaruhi budaya politik di sebuah negara. ${ }^{28}$

Sebagaimana yang diketahui bersama bahwa pemilu di Indonesia pertama kali dilaksanakan di Indonesia sejak tahun 1955. Sejak pemilu pertama di Indonesia menganut sistem proporsional di dalam pemilu. Di dalam sistem ini, alokasi jumlah kursi di lembaga perwakilan didasarkan pada perolehan suara masing-masing peserta pemilu secara proporsional untuk memilih wakil-wakil rakyat yang akan duduk di parlemen artinya bahwa setiap daerah yang memiliki jumlah penduduk yang populasinya banyak akan memiliki jumlah kursi lebih banyak di DPR. Sistem pemilu (electoral system) merupakan salah satu instrumen kelembagaan penting di dalam negara demokrasi untuk mewujudkan tiga persyaratan demokrasi. ${ }^{29}$ Pelaksanaan pemilu yang free and fair yang merupakan sarana pelaksanaan kedaulatan rakyat disyaratkan guna menghasilkan pemerintahan yang demokratis. Sebagaimana yang disampaikan oleh J. Kristiadi bahwa fungsi pemilu itu sendiri. ${ }^{30}$

\section{Pengaruh Penerapan Pemilu Propor- sional Daftar Terbuka}

Sejak awal demokrasi mulai dilaksanakanan, partisipasi selalu menjadi inti dalam praktiknya. Seperti yang pernah terjadi pada masa Yunani Kuno, seseorang dianggap sebagai warga negara jika telah berpartisipasi dalam memberikan putusan dan memiliki jabatan. ${ }^{31}$ Dalam demokrasi perwakilan, lembaga-lembaga dalam sistem politik memang diminta bekerja menjalankan fungsinya dari pengelolaan aspirasi politik rakyat dan lembaga-lembaga tersebut melakukan berbagai aktivitas yang secara terus menerus mempengaruhi pendapat masyarakat. Peran lembaga-lembaga tersebut dalam

\footnotetext{
27 J. Kristiadi (ed.), Menyelenggarakan Pemilu Yang Bersifat Luber Dan Jurdil, $1^{\text {st }}$ ed. (Jakarta: Center For Strategic And International Studies, 1997), hlm. 3.

28 Pipit R. Kartawidjaja dan Mulyana W.Kusumah, Op. Cit., hlm. v-vi

29 Kacung Marijan, Loc Cit.

30 J.Kristiadi (eds), Op. Cit., hlm. 1.

31 Pengakuan tersebut terjadi jika kewarganegaraan bagi para laki-laki dewasa mengandung arti keterlibatannya dalam urusan-urusan publik. Lihat dalam Fitra Arsil, "Mencegah Pemilihan Umum Menjadi Alat Penguasa (To Prevent The General Election From Being A Tool of The Authority)". Jurnal Legislasi Indonesia, Vol. 9 No. 4, (Desember 2012): 571.
} 
pemerintahan perwakilan memang dibutuhkan sebagai mekanisme dan institusi bagi ekspresi kehendak kehendak rakyat yang diwakili. ${ }^{32}$

Keberadaan partai politik yang memiliki tugas menjadi penghubung yang sangat strategis antara proses-proses pemerintahan dengan warga negara. ${ }^{33}$ Seperti dikemukakan oleh Hans Kelsen bahwa partai politik merupakan kendaraan essensial dalam pembentukan kehendak politik. ${ }^{34}$ Namun demikian, partai politik hanya merupakan salah satu saja dari bentuk pelembagaan sebagai wujud ekspresi ideide, pikiran-pikiran, pandangan dan keyakinan bebas dalam masyarakat demokratis. ${ }^{35}$

Dalam konteks insfrastruktur politik, partai politik bekerja di wilayah itu bersama lembaga lain seperti kelompok kepentingan (interest group), kelompok penekan (pressure group), media massa dan tokoh politik. ${ }^{36}$ Kegiatan kampanye yang dilakukan oleh partai politik dapat dianggap bagian dari pendidikan politik masyarakat, jika proses komunikasi politik yang intens selama masa kampanye atau bahkan sebelum masa kampanye dimulai dapat berhasil menanamkan nilai, norma dan simbol politik yang didasarkan pada prinsip demokrasi. Wujud yang paling nyata adalah tingkat partisipasi masyarakat untuk menggunakan hak pilihnya dan memberi dukungan kepada partai politik atau caleg yang dianggap paling mewakili aspirasi masyarat.

Partai politik adalah penyalur dan penampung aspirasi rakyat, partai dapat melakukan serangkaian kegiatan yang dapat membentuk kader-kader partai yang berkuwalitas. Memang dalam sistem demokrasi yang terjadi di Indonesia cenderung pragmatis, para caleg yang populer dapat terpilih tanpa mempertimbangkan kapasitas kemampuan para caleg yang menduduki jabatan di parlemen. Kosekuensi dari prinsip pemilu proporsional daftar terbuka memungkinkan setiap calon akan berlomba untuk meraih simpati dari warga masyarkat. Persoalannya adalah banyaknya caleg yang sebatas populer tanpa memiliki kemampuan di bidang legislasi menduduki kursi parlemen. Selain itu, biaya politik menjadi semakin mahal karena setiap calon berlomba untuk memperoleh suara dari masyarakat.

Dalam sistem pemilu proporsional daftar terbuka, selain memiliki banyak kelebihan namun juga mempunyai kelemahan. Persaingan untuk memperebutkan kursi di perlemen sangat kompetitif, hal ini dikarenakan sistem perhitungan suara terbanyak yang digunakan. Persoalan yang akan timbul tentunya melahirkan persaingan antar calon peserta pemilu, bukan hanya para calon yang berbeda partai politik, tetapi juga para calon yang tergabung dalam satu partai politik yang sama untuk memperebutkan suara terbanyak. Calon mempunyai peluang yang sama untuk memenangkan kursi di parlemen.

Pemilih pada sistem pemilu ini mempunyai peran yang cukup kuat untuk dapat menentukan seseorang caleg, sehingga para caleg 
akan berlomba-lomba untuk memperoleh dukungan dari masyarakat. Penerapan sistem proporsional terbuka tersebut pada akhirnya akan menimbulkan persaingan antar sesama calon anggota legislatif baik itu sesama partai atau berbeda partai politik. Sehingga seringkali pendekatan finasial dilakukan untuk mempermudah proses pemenangan.

Tidak hanya untuk pemilu tahun 2009, pemilu-pemilu sebelumnya juga sudah terjadi pendekatan-pendekatan finansial yang dilakukan oleh caleg, hal ini mengakibatkan biaya politik yang menjadi mahal, karena untuk mendapat kursi di parlemen, para caleg harus mengeluarkan biaya yang besar untuk kampanye kepada masyarakat. Jika melihat dari daftar dana kampanye yang dipublikasikan di situs resmi Komisi Pemilihan Umum, akan terlihat besarnya dana yang dikeluarkan oleh setiap partai untuk pembiayaan kampanye. ${ }^{37}$

Pengaruh yang akan timbul dengan penerapan sistem proporsional daftar terbuka ini selain akan mengakibatkan biaya kampanye yang tinggi, juga akan melahirkan pemilih yang pragmatis. Para pemilih akan cenderung memilih para calon yang kuat secara finansial. Selain melahirkan pemilih yang pragmatis, juga berakibat pada kinerja calon anggota legislatif yang terpilih yang tidak optimal. Mengingat pada saat caleg tersebut mengeluarkan banyak dana untuk kampanye, maka mereka akan cenderung berpikir agar dana yang telah mereka keluarkan dapat kembali. Data tersebut dapat dilihat dari data yang dikeluarkan oleh Komisi Pemberantas
Korupsi yang telah merilis bahwa sebagian besar koruptor berasal dari anggota legislatif baik tingkat nasional maupun di daerah. ${ }^{38}$

\section{Problem Sistem Pemilu Proporsional Daftar Terbuka}

Sistem daftar terbuka sendiri pada dasarnya merupakan hasil sebuah kompromi. Dalam pembahasan RUU mengenai Pemilu pada tahun 2002, PDIP, Golkar, dan PPP menolak usulan sistem daftar terbuka. Alasannya, penentuan caleg merupakan hak partai peserta pemilu. Memang, diberlakukannya sistem daftar terbuka, akan merugikan otoritas partai di dalam menyeleksi caleg mana saja yang didapandang lebih tepat untuk duduk di parlemen. Tetapi, tiga partai itu pada akhirnya menyetujui perubahan. Hanya saja, perubahannya tidak terbuka secara bebas, melainkan setengah terbuka. ${ }^{39}$

Mengingat sistem pemilu pada tahun 2004, tidak sepenuhnya mempergunakan sistem pemilu proporsional terbuka, perubahanperubahan desain kelembagaan seperti itu pada kenyataannya tidak membawa perubahan yang berarti. Terdapat beberapa penyebab; Pertama, pada kenyataannya para pemilih tetap lebih suka memilih calon yang terdapat di dalam daftar pemilih. Kecenderungan seperti ini memang wajar saja terjadi mengingat memilih tanda gambar saja itu lebih mudah jika dibandingkan dengan menggabungkan antara memilih tanda gambar dan daftar calon. Selain itu, dalam kampanye, para pengurus partai banyak yang menyerukan agar para pendukungnya cukup

37 http://www.kpu.go.id/index.php?option=com_content\&task=view\&id=8522\&Itemid=499, (diakses 19 Maret 2014).

38 http://acch.kpk.go.id/statistik-penanganan-tindak-pidana-korupsi-berdasarkan-tahun, (diakses 19 Maret 2014).

39 Lihat Kacung Marijan, Op.Cit., hlm. 96. 
memilih tanda gambar saja. Seruan demikian dilakukan agar para pilihan itu tidak salah. Di dalam aturan disebutkan, pemilih tanda gambar saja itu sah, sedangkan jika hanya memilih daftar calon itu tidak sah jika mengacu pada ketentuan sistem pemilu pada tahun 2004 yang didasarkan pada Undang-Undang Nomor 12 Tahun 2003. Kedua, sebagian besar calon yang dipilih tidak mampu memenuhi BPP. Dari keseluruhan calon di seluruh Indonesia, hanya ada dua calon yang dipilih memenuhi BPP, yaitu Hidayat Nur Wahid dari DP II Jakarta, dan Saleh Jasit dari DP Riau pada pemilu tahun $2004 .{ }^{40}$

Di samping itu, apabila dilihat dari tingkat keterwakilan (representativeness) masih mengandung masalah. Permasalahan ini khususnya berkaitan dengan perbandingan jumlah suara dengan jumlah alokasi kursi di DPR/D kepada partai-partai. Pada Pemilu 2004, misalnya dari 550 anggota DPR, yang murni terpilih berdasarkan BPP hanya 216 orang. Mereka terdiri dari Golkar 88, PDI-P 63, PKB 29, PKS 13, PD 9, PPP 8, PAN 5, dan PBB 1. Ketika sisa perolehan suara dihitung, masing-masing partai mendapat tambahan: Golkar 39, PDI-P 46, PKB 23, PKS 32, PD 47, PPP 50, PAN 48, dan PBB $10 .{ }^{41}$

Di sisi lain, nilai BPP antara DP yang satu dengan DP yang lain memiliki perbedaan. Paling tidak, hal ini terkait dengan dua hal. Pertama, terdapat upaya untuk mengakomodasi gagasan adanya keterwakilan yang berimbang antara Jawa dan luar Jawa. Kedua, secara kelembagaan terdapat keputusan bahwa satu DP minimal memiliki 3 kursi. Implikasi dari kebijakan demikian adalah terdapatnya DP-DP yang BPPnya berada di bawah rata-rata BPP nasional. Tetapi, ada juga yang berada di atas rata-rata BPP nasional. Secara nasional, pada pemilu 2004, BPP-nya adalah 206.346 orang. Sebagian besar DP yang memiliki BPP di bawah nilai nasional adalah di luar Jawa, seperti Papua = 95.619, Irian Jaya Barat $=97.477$, Kalimantan Selatan $=141.546$, Maluku Utara $=137.994$, dan Gorontalo 159.877. Sementara itu, di Jawa, rata-rata di atas BPP nasional. Contohnya, Jatim $I X=241.192$, Jatim VII $=253.658$, Jateng $\mathrm{VI}=$ 250.320 , Jateng $\mathrm{VIII}=259.685$, dan Jabar $\mathrm{I}=$ 258.585 .42

Sistem pemilu yang digunakan pada pemilu tahun 2014 tidak berbeda dari sistem pemilu tahun 2009, maupun pemulu 2004, tetapi persoalan yang muncul dengan tetap mempertahankan sistem proporsional daftar terbuka untuk pemilihan anggota DPR/DPRD berdampak pada besarnya biaya pemilu dari masing-masing caleg. Beberapa media memberitakan untuk menduduki kursi parlemen seorang calon anggota DPR harus mengeluarkan biaya ratusan juta bahkan milyar.

\section{E. Penutup}

Dampak dari putusan Mahkamah Konstitusi Nomor 22 dan 24/PUU-VI/2008 yang mengabulkan permohonan uji materiil Pasal 214 Undang-Undang Nomor 10 Tahun 2008 tentang Pemilihan Umum Anggota DPR, DPD dan DPRD, yakni mengubah sistem Pemilu legislatif dari sistem proporsional tertutup menjadi proporsional sistem terbuka. Sistem pemilu 
proporsional daftar terbuka, memang memiliki banyak kelebihan tetapi juga mempunyai kelemahan. Pengaruh yang akan timbul dengan penerapan sistem proporsional daftar terbuka ini selain akan mengakibatkan biaya kampanye yang tinggi, juga akan melahirkan pemilih yang pragmatis. Para pemilih akan cenderung memilih para calon yang kuat secara finansial. Sebagian besar calon yang dipilih tidak mampu memenuhi Bilangan Pembagi Pemilih yang pada akhirnya partai yang berwenang untuk menentukan siapa calon yang akan duduk di parlemen.

\section{DAFTAR PUSTAKA}

\section{Buku}

Asshiddiqie, Jimly, Pokok-Pokok Hukum Tata Negara Indonesia Pasca Reformasi, $2^{\text {nd }}$ ed. (Jakarta: PT Bhuana Ilmu Populer, 2008).

Asshiddiqie, Jimly, Kemerdekaan Berserikat, Pembubaran Partai Politik dan Mahkamah Konstitusi (Jakarta: Konstitusi Press, 2005).

Bailey, Kenneth D, Methods of Social Research, Second Edition (New York: The Free PressDevision of MacMillan Publishing Co. Inc, 1982).

Budiarjo, Miriam, Dasar-Dasar IImu Politik, $2^{\text {nd }} \mathrm{ed}$., (Jakarta: PT Gramedia, 1978).

Fahmi, Khairul, Pemilihan Umum Dan Kedaulatan Rakyat, 1st ed. (Jakarta: PT Raja Grafindo Persada, 2011).

Kelsen, Hans, General Theory of Law and State (New York: Russel \& Russel, 1961).

Kristiadi, J, Menyelenggarakan Pemilu Yang Bersifat Luber Dan Jurdil, $1^{\text {st }}$ ed. (Jakarta: Center For Strategic And International Studies, 1997).

Marijan, Kacung, Sistem Politik Indonesia; Konsolidasi Demokrasi Pasca-Orde Baru, (Jakarta: Kencana, 2012).
Nurtjahjo, Hendra, Filsafat Demokrasi, (Jakarta: Bumi Aksara, 2006).

Pipit R. Kartawidjaja dan Mulyana W.Kusumah, Sistem Pemilu Dan Pemilihan Presiden: Suatu Studi Banding (Jakarta: KIPP Eropa, Friedrich Naumann Stiftung dan Indonesian Society For Democracy And People Employment, 2002).

Safa'at, Muchamad Ali, Pembubaran Partai Politik: Pengaturan dan Praktik Pembubaran Partai Politik dalam Pergulatan Republik, (Jakarta: Rajawali Press, 2011).

Shick, Ruppert and Wolfgang Zek, The German Budestag: Functions And Procedurs, $1^{\text {st }}$ ed., Rheinbretbach (Neve Darmstadter Verlagsanstalt, 1999).

Soekanto, Soerjono dan Sri Mamudji, Penelitian Hukum Normatif Suatu Tinjauan Singkat (Jakarta: PT RajaGrafindo Persada, 2009).

Soemantri, Sri, Tentang Lembaga-Lembaga Negara Menurut UUD 1945, $4^{\text {th }}$ ed., (Bandung: Citra Aditya Bakti, 1989).

\section{Makalah / Artikel / Prosiding / Hasil Penelitian}

Arsil, Fitra, "Mencegah Pemilihan Umum Menjadi Alat Penguasa (To Prevent The General Election From Being A Tool of The Authority)". Jurnal Legislasi Indonesia, Vol. 9 (2012).

\section{Internet}

Dwi Aroem Hadiati dalam: http://politik.kompasiana. com/2014/01/07/sistem-proporsional-terbukamasih-pilihan-terbaik-626328.html, (diakses 25 Februari 2014).

http://id.voi.co.id/voi-komentar/4955-tidak-adasystem-pemilu-yang-dianggap-terbaik, (diakses 26 Februari 2014).

http://www.kpu.go.id/index.php?option=com_cont ent\&task=view\&id=8522\&ltemid=499, (diakses 19 Maret 2014).

http://acch.kpk.go.id/statistik-penanganan-tindakpidana-korupsi-berdasarkan-tahun, (diakses 19 Maret 2014). 